\author{
Sylwia Żakowska \\ Katarzyna Podhorodecka \\ ORCID 0000-0003-3075-7453 \\ Uniwersytet Warszawski \\ Wydział Geografii i Studiów Regionalnych \\ Katedra geografii Regionalnej i Politycznej \\ kpodhorodecka@uw.edu.pl
}

\title{
ROZMIESZCZENIE WALORÓW TURYSTYCZNYCH A LOKALIZACJA NOCLEGOWEJ BAZY TURYSTYCZNEJ W WOJEWÓDZTWIE ŁÓDZKIM ${ }^{1}$
}

\begin{abstract}
Abstrakt: $W$ artykule przedstawiono zależność pomiędzy walorami przyrodniczymi i pozaprzyrodniczymi a rozmieszczeniem turystycznej bazy noclegowej w 24 powiatach województwa łódzkiego. Ukazano podział na walory przyrodnicze i pozaprzyrodnicze oraz omówiono ich występowanie w poszczególnych powiatach. Następnie scharakteryzowano turystyczną bazę noclegową województwa łódzkiego. Przedstawiono również dane statystyczne dotyczące tworzących ją obiektów. Istotnym elementem opracowania było zaprezentowanie wyników badania, przeprowadzonego z wykorzystaniem metody bonitacji punktowej. Na etapie końcowym obliczono wskaźnik korelacji rang Spearmana, dzięki czemu ukazano stopień zależności pomiędzy wybranymi walorami turystycznymi a rozmieszczeniem turystycznej bazy noclegowej.
\end{abstract}

Słowa kluczowe: walor turystyczny, walory przyrodnicze, walory kulturowe, turystyczna baza noclegowa, turystyka, korelacja rang Spearmana.

\section{WPROWADZENIE}

W artykule przedstawiono wyniki analizy zależności pomiędzy rozmieszczeniem turystycznej bazy noclegowej a występowaniem walorów przyrodniczych i pozaprzyrodniczych w województwie łódzkim. Głównym celem autorki jest uzyskanie odpowiedzi na pytanie, które walory (przyrodnicze czy kulturowe) mają silniejszy wpływ na rozmieszczenie bazy noclegowej w województwie łódzkim. W badaniach wykorzystano metodę bonitacji punktowej. Opracowane wyniki bonitacji punktowej walorów turystycznych oraz dane dotyczące pojemności bazy noclegowej zostały skorelowane za pomocą współczynnika Spearmana². Założono, że największy wpływ na rozmieszczenie bazy noclegowej będą miały walory przyrodnicze, a szczególnie występowanie obszarów przyrody chronionej, w których pobliżu powinny być zlokalizowane obiekty noclegowe.

Powstanie przestrzeni turystycznej uwarunkowane jest bowiem istnieniem ruchu turystycznego (WŁODARCZYK 2009), a walory turystyczne o charakterze wypoczynkowym $\mathrm{z}$ reguly występują na terenach o malowniczym krajobrazie. Sa to miejsca słabo zurbanizowane i umożliwiające kontakt z przyrodą, w których panuje korzystny klimat (KRUCZEK 2008, s. 14-64).
Za główny walor przyrodniczy uważa się ukształtowanie powierzchni ziemi, od której zależy występowanie pozostałych walorów. Dla turystów istotne są: istnienie cieków i zbiorników wodnych, temperatura wody, głębokość czy rodzaje brzegów. Niezwykle ważna jest szata roślinna oraz świat zwierzęcy, które podnoszą atrakcyjność obszaru dla każdego rodzaju turystyki (GOŁEMBSKI 2006). Infrastruktura uzdrowiskowa ma związek z walorami przyrodniczymi, wodami geotermalnymi i ogólnym oddziaływaniem środowiska naturalnego na zdrowie ludzi. W turystyce ważną rolę odgrywają również elementy przyrodnicze, które wytworzył lub pomógł wytworzyć człowiek, np. zabytkowe parki, muzea i zbiory przyrodnicze, ogrody botaniczne czy zoologiczne. Punkty widokowe nie tworzą wprawdzie samodzielnego waloru turystycznego, ale dają możliwość prowadzenia rozległych obserwacji i podziwiania krajobrazu. Kolejnymi walorami są powszechnie znane wielkoprzestrzenne formy ochrony przyrody: parki narodowe i krajobrazowe oraz rezerwaty przyrody (LIEWSKI, MIKUŁOWSKI, WYRZYKOWSKI 2002).

Walory kulturowe, zwane także antropogenicznymi, związane są nie tylko $\mathrm{z}$ historią, archeologią, 
martyrologią czy twórczością ludową, ale również ze sztuką. Zabytki architektury, budownictwa, działalności gospodarczej i techniki, obiekty historyczno-wojskowe, a także miejsca kultu pielgrzymkowego oraz współczesne imprezy kulturalne to również walory kulturowe. Według A. KOWALCZYKA (2001) turyści coraz częściej odwiedzają zabytki poprzemysłowe i obiekty techniki.

\section{ANALIZA LITERATURY}

Poniżej przedstawiono przegląd zawartych w literaturze informacji na temat walorów przyrodniczych i kulturowych oraz specyfiki turystyki przemysłowej. Pojęciami ściśle związanymi z turystyką są wypoczynek i rekreacja. Wypoczynek oznacza zazwyczaj jakąś formę turystyki pobytowej, sprzyjającej odnowie kondycji psychicznej i fizycznej człowieka. Rekreacją natomiast nazywany jest proces regeneracji sił oraz uczestniczenie po pracy czy szkole (w czasie wolnym) w rozrywkach kulturalnych, sportowych lub innych (WARSZYŃSKA, JACKOWSKI 1978).

Według T. JĘDRYSIAKA (2008) walory turystyczne często utożsamia się z atrakcjami turystycznymi, a według G. GOŁEMBSKIEGO (2006) walory te sa jednym z elementów składowych atrakcyjności turystycznej. Pozostałe składowe to stan i ochrona środowiska naturalnego oraz dostępność komunikacyjna. Często podkreśla się, że walor turystyczny jest elementem mającym charakter obiektywny, natomiast atrakcyjność turystyczna jest subiektywną oceną wystawianą przez turystów. Według S. WODEJKI (1997) wraz ze wzrostem świadomości turystycznej coraz istotniejsza staje się ocena atrakcyjności. Większość czynników sprzyjających turystyce wypoczynkowej została ukształtowana przez naturę, bez ingerencji człowieka (skały, głazy, gleba, rzeźba terenu, jaskinie, groty, wody powierzchniowe i podziemne oraz wąwozy i doliny) (KUREK 2007), natomiast walorami krajoznawczymi mogą być bardzo różne elementy środowiska zarówno przyrodniczego, jak i antropogenicznego, w zależności od indywidualnych zainteresowań turystów (ROGALEWSKI 1972).

Niewątpliwie istotnym walorem kulturowym są muzea o różnorodnej tematyce - mogą to być placówki poświęcone znanym osobom (biograficzne), historyczne, archeologiczne, etnograficzne, związane ze sztuką czy techniką. Szczególnym rodzajem muzeów są skanseny, w których nie tylko chroni się tradycyjne budownictwo wiejskie, ale także kultywuje obrzędy, tradycje i twórczość ludową. Za ważny rodzaj walorów antropogenicznych uznaje się współczesne imprezy kulturalne, w tym zwłaszcza wydarzenia muzyczne i sportowe. Coraz więcej osób odwiedza rów- nież obiekty kulturalno-widowiskowe, takie jak teatry czy filharmonie (KOWALCZYK 2001).

Dodatkowo $\mathrm{w}$ województwie łódzkim istotną rolę odgrywa turystyka przemysłowa, polegająca na odwiedzaniu obszarów, na których w przeszłości rozwijał się przemysł. Przykładami są dawne kopalnie, zakłady przemysłowe, obiekty i urządzenia, umożliwiające rozwój techniki, a także stare maszyny oraz zabytkowe młyny. Turyści chętnie odwiedzają również muzea techniki i przemysłu oraz wciąż funkcjonujące przedsiębiorstwa (DEREK 2010).

Według S. KACZMAREK (2001) miasta przeprowadzające restrukturyzacje gospodarki po upadku przemysłu $\mathrm{z}$ reguły znajdują się $\mathrm{w}$ bardzo trudnej sytuacji ekonomicznej i społecznej, a turystyka poprzemysłowa może być jedną z możliwości poszukiwania nowych impulsów do rozwoju i źródeł dochodów dla mieszkańców. Obecnie na listę Europejskiego Szlaku Dziedzictwa Przemysłowego wpisanych jest 1630 obiektów. W Polsce zlokalizowanych jest $80 \mathrm{z}$ nich, z czego trzy znajdują się na terenie województwa łódzkiego (kompleks Manufaktura, Centralne Muzeum Włókiennictwa w Łodzi i kompleks EC1) (www.erih.net). Przemysł na ziemiach polskich rozwijał się już wprawdzie od końca XVIII w., ale w przypadku Łodzi kluczowy jest XIX w. Przełomowym wydarzeniem, które zapoczątkowało rozwój łódzkiego okręgu włókienniczego, było utworzenie w 1820 r. osady fabrycznej (KRONENBERG 2012).

W ostatnim czasie uwagę turystów zwracają również inne zabytki techniki, związane np. z komunikacją: dawne linie kolejowe, parawozownie, a zwłaszcza odnawiane i ponownie uruchamiane kolejki wąskotorowe (KOWALCZYK 2001).

Turystyka jest zjawiskiem ekonomicznym i daje możliwość pokazania kultury poszczególnych miejsc. To właśnie dzięki turystyce można poznać różnorodność kulturową wielu regionów oraz jej mieszkańców, jednak dostrzegalny jest również proces przenikania się kultur na skutek obcowania ze sobą różnych ludzi (PRZECŁAWSKI 1997). Wielu autorów opracowań o tematyce związanej z turystyką oraz jej aspektami wspomina o modelach atrakcyjności "3S" (sea, sun, sand), "4A" (attractions, amenities, accommodation, access) oraz "3E" (entertainment, excitement, education) (WIĘCKOWSKI 2014). Turystyka w województwie łódzkim ma wiele do zaoferowania, szczególnie $\mathrm{w}$ ramach ostatniego modelu, tj. , 3E".

Ze względu na mnogość wspólnych cech istniejącą już podaż turystyczną można porównywać z atrakcyjnością turystyczną, która w dużej mierze decyduje o poziomie atrakcyjności regionów (WARSZYŃSKA, JACKOWSKI 1978). Poprzez podaż turystyczną rozumie się „ilość produktu turystycznego oferowaną na sprzedaż przy danej cenie i w danym okresie" (WODEJKO 1997, s. 23). Obszar, w którego ramach rozwija się funk- 
cja turystyczna, określa się mianem przestrzeni turystycznej. Jest ona wydzielana na podstawie pełnionych funkcji i według B. WŁODARCZYKA (2009) odgrywa nadrzędną rolę $\mathrm{w}$ badaniach turystycznych. J. WARSZYŃSKA i A. JACKOWSKI (1978, s. 31) definiują ją jako „część przestrzeni geograficznej i społeczno-ekonomicznej, w której zachodzą zjawiska turystyczne".

\section{TURYSTYCZNE WALORY PRZYRODNICZE WOJEWÓDZTWA ŁÓDZKIEGO}

Województwo łódzkie składa się z 24 powiatów. Znajdują się w nim 44 miasta, z których trzy (Skierniewice, Piotrków Trybunalski oraz stolica województwa - Łódź) posiadają prawa powiatu. Największym miastem zarówno pod względem powierzchni, jak i liczby ludności jest Łódź (odpowiednio 293,25 km² oraz 693,8 tys. osób) ${ }^{3}$, na drugim miejscu - z powierzchnią $67,24 \mathrm{~km}^{2}$ i 74,9 tys. mieszkańców - sytuuje się Piotrków Trybunalski (www.bdl.stat.gov.pl). Województwo łódzkie zajmuje 18,2 tys. $\mathrm{km}^{2}$, co stanowi blisko $6 \%$ powierzchni kraju. Pod względem liczby ludności plasuje się na szóstej pozycji, jednak mieszkańców wciąż ubywa (www.stat.gov.pl/bdl) ${ }^{4}$.

Teren opisywanego województwa znajduje się na Nizinach Środkowopolskich (Nizinie Środkowomazowieckiej, Południowowielkopolskiej i Wzniesieniach Południowomazowieckich), a także $\mathrm{w}$ niewielkiej części na Wyżynie Małopolskiej oraz Wyżynie Śląsko-Krakowskiej (KRUCZEK 2005). Region położony jest w centrum kraju. Miejscowość Piątek, w powiecie łęczyckim, uznawana jest za geometryczny środek Polski. Ponadto pod Strykowem krzyżują się dwa główne szlaki komunikacyjne - autostrady A1 i A2.

Region łódzki nie posiada szczególnie zróżnicowanej rzeźby terenu - mimo wyżynnego charakteru brak tu znaczących wzniesień. Najwyższe z nich - Góra Kamieńska - jest sztuczne i powstało jako zwałowisko zewnętrzne Kopalni Węgla Brunatnego „Bełchatów”. Ma ono wysokość bezwzględną 386 m n.p.m. Obszar ten został zalesiony oraz zrekultywowany (www.lodz kie.travel.pl). Drugie najwyższe wzniesienie regionu to Fajna Ryba (374 m n.p.m.), znajdująca się w powiecie radomszczańskim, w gminie Przedbórz.

Obszar dzisiejszego województwa łódzkiego do $1820 \mathrm{r}$. był bardzo zasobny w lasy, jednak w związku z gwałtownym rozkwitem przemysłu, niekontrolowanym rozwojem Łodzi oraz jej przedmieść dobra te zostały bezpowrotnie utracone. Ścinane drzewa wykorzystywano do celów budowlanych oraz jako opał. Innym powodem wycinki lasów była chęć pozyskania terenów przeznaczanych pod zabudowę miejską. W efekcie województwo łódzkie ma obecnie najniższą lesistość (21,4\%) spośród wszystkich 16 województw w kraju (Raport o stanie lasów... 2017).

Rozkwit przemysłu w dużej mierze przyczynił się do znaczącej degradacji środowiska przyrodniczego zarówno w Łodzi, jak i w całym regionie (KOTER, LISZEWSKI, SULIBORSKI 1999). W związku z likwidacją lasów zmniejszyła się retencja, co spowodowało obniżenie poziomu wód gruntowych. Stan rzek z czasem coraz bardziej się pogarszal, przez co zakłady przemysłu włókienniczego, w wysokim stopniu wodochłonne, napotkały $\mathrm{w}$ latach 70 . XX w. istotną barierę rozwoju.

$\mathrm{W}$ drugiej połowie $\mathrm{XX} \mathrm{w}$. $\mathrm{w}$ regionie łódzkim zbudowano dwa sztuczne zbiorniki wodne: Zalew Sulejowski (na Pilicy) oraz Jeziorsko (na Warcie). Ich otoczenie zostało dostosowane do potrzeb turystyki - wokół akwenów znajdują się kąpieliska, plaże oraz lasy (KOTER, LISZEWSKI, SULIBORSKI 1999). W pobliżu sulejowskiego zbiornika wodnego usytuowany jest rezerwat Groty Nagórzyckie, a także wywierzysko Niebieskie Źródła (w granicach Tomaszowa Mazowieckiego). Źródło to ma turkusową barwę i stanowi unikatowy w skali Polski rezerwat przyrody (LIJEWSKI, MIKUŁOWSKI, WYRZYKOWSKI 2002). Drugi ze wspomnianych zbiorników wodnych sam w sobie jest mniej atrakcyjny dla turystów poszukujących wypoczynku, jednak należy pamiętać, że stanowi on ostoję wielu gatunków ptaków wodnych i wodno-błotnych (LIJEWSKI, MIKUŁOWSKI, WYRZYKOWSKI 2002). Z tego powodu utworzono tu faunistyczny rezerwat przyrody Jeziorsko.

W granicach województwa znajduje się kilka znanych w całym kraju kompleksów roślinności, ukształtowanych ręką człowieka. Są to m.in. historyczne założenia pałacowo-ogrodowe: barokowy park w Nieborowie oraz romantyczno-sentymentalny park w Arkadii. Historia pałacu w Nieborowie (miejscowości powstałej w XII w.) sięga końca XVII w., ale projektowanie otaczającego go ogrodu francuskiego rozpoczęto pod koniec XVII w. Z kolei w pobliskim parku w Arkadii można zobaczyć następujące budowle, powstałe w XIX w.: Grotę Sybilli, Świątynię Diany, akwedukt, Domek Gotycki oraz Dom Murgrabiego (www.niebo row.art.pl).

Kolejnym walorem, który ma jednocześnie charakter przyrodniczy i pozaprzyrodniczy, są ogrody botaniczne, muzea oraz zbiory przyrodnicze. Najliczniejszą grupę ogrodów stanowią w Polsce ogrody dendrologiczne, czyli arboreta. Jedno z nich zlokalizowane jest w miejscowości Rogów. Arboretum rogowskie zostało stworzone od podstaw jako zakład doświadczalny SGGW w Warszawie (EUKASZEWICZ 1987). Obiekt ten jest jednym $z$ największych $w$ Polsce i ma charakter parku leśnego. Kolekcja roślin, jakimi dysponuje, jest jedna z najbogatszych i najciekawszych w Europie Środkowo-Wschodniej. Istnieje tu też m.in. Muzeum Lasu i Drewna (www.arboretum.sggw.pl). 
Innym obiektem przyrodniczym typu antropogenicznego jest łódzki Ogród Botaniczny wraz z Palmiarnią - jeden $\mathrm{z}$ największych ogrodów $\mathrm{w}$ Polsce. Zajmuje on powierzchnię 67 ha i ma charakter parkowo-leśny (www.uml.lodz.pl).

Szczególnie cenne, wyjątkowe pod względem przyrodniczym tereny objęte są ochroną prawną. Analizie metodą bonitacji punktowej poddane zostały trzy rodzaje takich obszarów: parki narodowe, rezerwaty przyrody i pomniki przyrody. $W$ opracowaniu omówiono ich występowanie $\mathrm{w}$ poszczególnych powiatach województwa oraz wpływ na rozmieszczenie turystycznej bazy noclegowej. Parki krajobrazowe uznano za obszary o mniejszym znaczeniu i dlatego nie zostały uwzględnione $\mathrm{w}$ analizie.

Wśród wielkoprzestrzennych form ochrony przyrody najważniejsze są parki narodowe. $W$ województwie łódzkim istnieje jeden taki obiekt. Jest to Ośrodek Hodowli Żubrów w Smardzewicach (powiat tomaszowski), który jako enklawa został włączony do Kampinoskiego Parku Narodowego w 1976 r. Na powierzchni 72,4 ha hodowanych jest tam obecnie około 20 zwierząt tego gatunku (OLACZEK 2013).

$\mathrm{Na}$ terenie województwa łódzkiego znajduje się sześć rezerwatów przyrody, których zadaniem jest ochrona niepospolitych gatunków drzew. Za wyjątkowy walor turystyczny uznano zwłaszcza, zlokalizowany w powiecie piotrkowskim, rezerwat przyrody Las Jabłoniowy. Zajmuje on powierzchnię 19 ha. Został utworzony $w$ celu ochrony rosnącej $w$ tym rejonie dużej liczby dzikich drzew owocowych. Wśród drzew, takich jak: dąb, grab, brzoza, jarząb pospolity (potocznie zwany jarzębiną), swoje siedlisko ma tam dzika jabłoń oraz grusza pospolita (OLACZEK 2013).

Interesujące są również rezerwaty chroniące drzewostany pamiątkowe. $\mathrm{W}$ województwie znajduje się ich pięć: Starodrzew Lubochniański, Gaik, Spała, Dęby w Meszczach im. Jeremiego Kozłowskiego oraz Uroczysko Bażantarnia (OLACZEK 2013). Atutem tego terenu jest także Zespół Przyrodniczo-Krajobrazowy Zwierzyniec Królewski o powierzchni 572 ha (www.skier niewice.lodz.lasy.gov.pl).

Ostatnią grupę obiektów poddanych analizie stanowią pomniki przyrody. Mogą nimi być: pojedyncze drzewa, grupy drzew, zabytkowe aleje, głazy narzutowe, a także skałki, groty i jaskinie (www.lodzkie. travel.pl). W 2016 r. w województwie łódzkim znajdowało się 3249 pomników przyrody. Najbardziej charakterystycznym przykładem powierzchniowego pomnika przyrody jest park Źródliska w Łodzi. Obecnie składa się on $z$ dwóch części, a pomiędzy nimi znajduje się dawna fabryka oraz pałac Karola Scheiblera - największego łódzkiego fabrykanta (www.kul tura. lodz.pl; www.lodz.naszemiasto.pl).

\section{KULTUROWE WALORY TURYSTYCZNE WOJEWÓDZTWA ŁÓDZKIEGO}

O dzisiejszym wyglądzie Łodzi decyduje przede wszystkim architektura XIX-wieczna. Niezwykle dynamiczny rozwój przemysłu włókienniczego w tym stuleciu zaznaczył się w krajobrazie kulturowym licznymi obiektami z charakterystycznej czerwonej cegły (MOKRAS-GRABOWSKA 2014). Zabytki architektury pochodzące ze starszych epok znajdują się poza stolicą regionu.

W województwie zlokalizowanych jest wiele średniowiecznych grodzisk, np. w Tumie i Sieradzu. Na miejscu dawnych grodów powstawały zamki, których historia do dziś tworzy wartość historyczno-kulturową regionu, jak np. w Uniejowie, Łęczycy czy Piotrkowie Trybunalskim. $W$ regionie zachowały się również liczne szlacheckie dwory i pałace oraz rezydencje magnackie, np. w Nieborowie. W Skierniewicach $\mathrm{z}$ kolei znajduje się jedyny $\mathrm{w}$ okolicy pałac biskupi, pochodzący z początku XVII w. (KOTER, LISZEWSKI, SULIBORSKI 1999).

Muzea archeologiczne i etnograficzne, a także skanseny oraz ośrodki twórczości ludowej występują w całym regionie. Przejawy tradycyjnej kultury ludowej widać zwłaszcza na terenie powiatu łowickiego oraz opoczyńskiego, których folklor znany jest nie tylko w Polsce, ale i na świecie. Przykładem wsi z zachowaną zabytkową zabudową jest Złaków Borowy. W Łowiczu znajduje się muzeum, na którego dziedzińcu usytuowane są dwie tradycyjne zagrody łowickie. Najpelniej materialną i niematerialną kulturę Księżaków łowickich prezentuje jednak skansen w Maurzycach koło Łowicza (LIJEWSKI, MIKUŁOWSKI, WYRZYKOWSKI 2008).

Do najważniejszych walorów kulturowych zalicza się obiekty architektury sakralnej. Najstarsze kościoły romańskie powstały $\mathrm{w}$ regionie lódzkim na początku XI w. Z tego okresu pochodzi m.in. kolegiata w Tumie (KRUCZEK 2005). Świątynie w stylu gotyckim tworzono od XIV do XVI w. W kolejnych stuleciach zbudowano jeszcze wiele kościołów katolickich, zwłaszcza w stylu barokowym. W okresie zaboru rosyjskiego (XIX w.) w regionie pojawily się cerkwie prawosławne, m.in. w Łodzi i Piotrkowie Trybunalskim. Z kolei napływ niemieckich osadników, związany z rozwojem przemysłu włókienniczego, zaowocował budową zborów protestanckich, m.in. w Łodzi, Pabianicach, Tomaszowie Mazowieckim i Zduńskiej Woli (świątynie ewangelicko-augsburskie z XIX w.). Jedynym przykładem świątyni ewangelicko-reformowanej jest kościół w Zelowie (KOTER, LISZEWSKI, SULIBORSKI 1999).

Kolejnym walorem antropogenicznym regionu łódzkiego są pochodzące z różnych okresów historycznych układy urbanistyczne. Oprócz typowych 
średniowiecznych założeń przestrzennych $\mathrm{z}$ prostokątnym rynkiem w centrum (np. Piotrków Trybunalski, Sieradz) istnieją również rzadziej spotykane zespoły urbanistyczne. Przykładem może być Łowicz, słynący z dwóch rynków, w tym jednego trójkątnego, a także Łódź, rozwijająca się w XIX w. wzdłuż ulicy Piotrkowskiej, rozpoczynającej się na ośmiobocznym placu, tzw. Nowym Rynku (dziś plac Wolności).

Wzrost popularności turystyki przemysłowej i poprzemysłowej może okazać się dużą szansą dla Łodzi. Dużym atutem tego typu podróży jest brak wyraźnej sezonowości, będący cechą niewielu rodzajów turystyki (JĘDRYSIAK 2008). W ostatnich latach podupadłe XIX-wieczne kompleksy fabryczne (wille i pałace fabrykantów, zakłady przemysłowe, osiedla robotnicze) poddawane są intensywnym procesom rewitalizacyjnym. Najlepszym i najbardziej znanym przykładem jest przeobrażenie dawnej fabryki Izraela Poznańskiego w centrum handlowo-rozrywkowe Manufaktura. Dla zwiedzających otwarto Muzeum Fabryki i Muzeum Sztuki $\left(\mathrm{ms}^{2}\right)$, a w byłym pałacu fabrykanta już od 1975 r. funkcjonuje Muzeum Miasta Łodzi (KRONENBERG 2012). Aktualnie odnawiane są famuly - domy robotników. Rozpoczęła się także rewitalizacja Księżego Młyna - największego kompleksu fabrycznego w Łodzi, należącego do „króla bawełny”, tj. Karola Scheiblera.

Pierwszym obiektem poprzemysłowym, udostępnionym turystom, był jednak dawny zespół fabryczny Ludwika Geyera, w którym mieści się Centralne Muzeum Włókiennictwa. Wiele innych obiektów poprzemysłowych, jak np. zespoły fabryczne Karola Bennicha, Juliusza Kindermanna czy Ernesta Wevera, nadal jest wykorzystywanych - część z nich przekształcono w muzea lub galerie sztuki, w pozostałych zlokalizowano hotele lub restauracje. Najnowszym spektakularnym przykładem rewitalizacji jest kompleks łódzkiej elektrociepłowni EC1, w którym po gruntownym remoncie otwarto nowoczesne Planetarium i Centrum Nauki i Techniki EC1. W budowie jest Centrum Komiksu i Narracji Interaktywnej oraz Narodowe Centrum Kultury Filmowej. Cały kompleks zlokalizowany jest w pobliżu dworca Łódź Fabryczna (KRONENBERG 2012).

Za ważny walor antropogeniczny uznawane są obiekty historyczno-wojskowe. Przykładem miejscowości, która posiada taki walor, może być Kutno, gdzie znajduje się Muzeum Bitwy nad Bzurą, czy Konewka k. Spały, gdzie można zobaczyć niemiecki schron kolejowy z czasów II wojny światowej. Turystów interesują też rekonstrukcje historycznych bitew, ważnych dla danego regionu. Takie inscenizacje odbywają się np. w Bolimowie (1914) i Strońsku (1939).

Unikatowym walorem kulturowym regionu jest dziedzictwo filmowe zarówno samej Łodzi (uznawanej niegdyś za stolicę polskiego filmu), jak i wielu innych miejscowości województwa, stanowiących scenografię znanych polskich i zagranicznych filmów (zwłaszcza Piotrków Trybunalski). W celu promocji obiektów i wydarzeń związanych z polską kinematografią powstały szlaki miejskie (np. Szlak Łodzi Bajkowej, „Piotrków Trybunalski na filmowej taśmie”) i regionalny szlak turystyczny "Łódzkie filmowe”. $\mathrm{W}$ ramach tego ostatniego wytyczono dla turystów zmotoryzowanych jedną dwudniową i dziewięć jednodniowych tras (KRONENBERG 2016).

Ostatnim wziętym pod wagę walorem pozaprzyrodniczym były wydarzenia kulturalne, cieszące się zainteresowaniem zarówno mieszkańców, jak i turystów. Z danych statystycznych wynika, że w Łodzi w 2016 r. odbyło się ich około 6 tys. Pozostałe powiaty wypadają pod tym względem zdecydowanie mniej atrakcyjnie. Na miejscu drugim znalazły się powiaty wieruszowski oraz pabianicki, w których zorganizowano niespełna 3 tys. wydarzeń (www.bdl.stat.gov. pl). Przykładami tego rodzaju imprez są Wędrowny Festiwal Filharmonii Łódzkiej „Kolory Polski” (koncerty różnych rodzajów muzyki w zabytkowych obiektach całego regionu) oraz przyciągający już ponad 600 tys. uczestników Festiwal Kinetycznej Sztuki Światła (Light Move Festival) w Łodzi.

Spośród wydarzeń o innym charakterze warto wspomnieć o organizowanym corocznie w Skierniewicach Święcie Kwiatów, Owoców i Warzyw (najstarszym w Polsce). Z kolei w Atlas Arenie w Łodzi (jednej z największych i najnowocześniejszych hal sportowo-widowiskowych w kraju) odbywają się międzynarodowe zawody w siatkówce czy koszykówce (także o randze mistrzostw Europy), koncerty gwiazd muzyki światowej, a także pokazy mody, wernisaże, wystawy i panele dyskusyjne.

\section{TURYSTYCZNA BAZA NOCLEGOWA WOJEWÓDZTWA ŁÓDZKIEGO}

Infrastrukturą turystyczną można nazwać wszelkiego rodzaju obiekty oraz urządzenia turystyczne, które mają na celu zaspokojenie potrzeb turystów. Bazę turystyczną dzieli się na noclegową, gastronomiczną, komunikacyjną i towarzyszącą (SZWICHTENBERG 2000). W niniejszej analizie skupiono się na bazie noclegowej, która uznawana jest za podstawowy miernik wielkości podaży turystycznej. Służy głównie turystom i jest zwykle zlokalizowana w miejscach, w których dominuje popyt na tego typu usługi (WODEJKO 1997). Ponadto hotele często powstają także $w$ dużych aglomeracjach miejskich.

Usługa noclegowa zaliczana jest do typowych usług turystycznych. W tej grupie znalazły się również usługi gastronomiczne, transportowe, organiza- 
cyjne, pilotażowe i informacyjne (KUREK 2007). Rozwój branży hotelowej można zaobserwować, gdy w małej odległości od siebie tworzone są różnej wielkości oraz różnego typu obiekty noclegowe. Mówi się wówczas o powstawaniu aglomeracji turystycznej (KOWALCZYK 2001).

Podział bazy noclegowej został opracowany przez Światową Organizację Turystyki (UN World Tourism Organization). Zgodnie z nim baza noclegowa dzieli się na hotelową oraz uzupełniającą (inaczej komplementarną). Do bazy hotelowej zaliczane są hotele, motele, pensjonaty oraz zajazdy. Bazę komplementarną tworzą pozostałe obiekty noclegowe. Światowa Organizacja Turystyki stworzyła pojęcie turystycznego obiektu noclegowego, oznaczające „każdy obiekt, w którym regularnie lub sporadycznie nocują turyści” (WODEJKO 1997, s. 40). Baza noclegowa zbiorowego zakwaterowania obejmuje także domy wycieczkowe, domy turysty, schroniska (m.in. górskie) i campingi (LIJEWSKI, MIKUŁOWSKI, WYRZYKOWSKI 2002).

Dane statystyczne, dotyczące bazy noclegowej w województwie łódzkim, zostały pozyskane z Banku Danych Lokalnych GUS. Pochodzą one z roku 2017 i dotyczą zarówno obiektów całorocznych, jak i działających sezonowo. W całym województwie łódzkim 48,6\% obiektów zbiorowego zakwaterowania stanowią hotele, a 1\% - motele, których jest dziewięć.

W 31 hotelach zlokalizowanych w Łodzi do dyspozycji gości pozostaje nieco ponad 5 tys. miejsc noclegowych. Na drugim miejscu pod względem liczby hoteli plasuje się powiat zgierski, w którym znajduje się ich osiem (łącznie mają one 563 miejsc noclegowych). Trzecie miejsce ex aequo zajmuja powiaty piotrkowski oraz pabianicki - w każdym z nich mieści się siedem obiektów hotelowych. Z kolei pod względem liczby miejsc noclegowych druga pozycję w regionie zajmuje powiat piotrkowski (902 miejsca noclegowe), potem powiat bełchatowski, w którym tylko w pięciu obiektach jest ich aż 595. Pensjonaty zlokalizowane są jedynie w dwóch powiatach - sieradzkim oraz tomaszowskim - i dysponują odpowiednio 48 oraz 41 miejscami noclegowymi.

Pozostałe obiekty zbiorowego zakwaterowanie zlokalizowane są na terenie wszystkich powiatów województwa. Największa liczba miejsc noclegowych w tego typu obiektach dostępna była w Łodzi i nieznacznie przekraczała 2 tys. Na drugim miejscu znalazł się powiat tomaszowski, z liczbą miejsc noclegowych około 1,8 tys. (www.bdl.stat.gov.pl).

\section{ZASADY BONITACJI PUNKTOWEJ WALORÓW TURYSTYCZNYCH}

Metoda bonitacji już w wielu publikacjach została wykorzystana do oceny walorów przyrodniczych (PIRASZEWSKA 2004, DRABAREK 2011, TERTELIS 2012). W tej pracy, aby określić syntetyczną wartość wskaźnika, poddano analizie zarówno turystyczne walory przyrodnicze, jak i antropogeniczne. Im więcej cech, którymi wyróżnia się region, tym większa szansa na to, że turyści o bardzo różnorodnych gustach znajdą w nim coś dla siebie (GOŁEMBSKI 1999). Trzeba jednak podkreślić, że metoda waloryzacji ma częściowo charakter subiektywny. Jak zauważył K. KOŻUCHOWSKI (2005), wyniki waloryzacyjnych badań środowiska nigdy nie są do końca obiektywne.

Niezwykle trudno jest dokonać oceny jakości oraz wartości poszczególnych walorów, w dużej mierze ze względu na ich subiektywny charakter. Można wymienić liczne wskaźniki, które określają jakość walorów turystycznych. Do walorów przyrodniczych zaliczono: udziały gruntów leśnych, powierzchni łąk i pastwisk, a także pozostałych gruntów i nieużytków w powierzchni gminy, rzeki w gminie według klas czystości, powierzchnie jezior w gminie też według klas czystości, wielkość deniwelacji, średnią temperaturę, sumę opadów, stosunek powierzchni chronionego

Tab. 1. Punktacja w metodzie bonitacji punktowej dla lesistości, powierzchni prawnie chronionych oraz pomników przyrody

\begin{tabular}{|c|c|c|c|c|c|c|c|c|}
\hline \multicolumn{9}{|c|}{ Bonitacja punktowa dla } \\
\hline \multicolumn{3}{|c|}{ lesistości } & \multicolumn{2}{c|}{ powierzchni prawnie chronionych } & \multicolumn{3}{c|}{ pomników przyrody } \\
\hline $\begin{array}{c}\text { przedziały } \\
\text { liczbowe } \\
(\%)\end{array}$ & $\begin{array}{c}\text { liczba } \\
\text { punktów } \\
\text { bonitacyj- } \\
\text { nych }\end{array}$ & $\begin{array}{c}\text { liczba } \\
\text { powiatów }\end{array}$ & $\begin{array}{c}\text { przedziały } \\
\text { liczbowe } \\
(\%)\end{array}$ & $\begin{array}{c}\text { liczba } \\
\text { punktów } \\
\text { bonitacyj- } \\
\text { nych }\end{array}$ & $\begin{array}{c}\text { liczba } \\
\text { powiatów }\end{array}$ & $\begin{array}{c}\text { liczba } \\
\text { przedziały } \\
\text { liczbowe } \\
\text { punktów } \\
\text { bonitacyj- } \\
\text { nych }\end{array}$ & $\begin{array}{c}\text { liczba } \\
\text { powiatów }\end{array}$ \\
\hline $0,1-10,0$ & 5 & 4 & $0,1-10,0$ & 2 & 5 & do 50 & 2 & 5 \\
\hline $10,1-20,0$ & 10 & 6 & $10,1-20,0$ & 4 & 9 & $51-100$ & 4 & 9 \\
\hline $20,1-30,0$ & 15 & 11 & $20,1-30,0$ & 6 & 7 & $101-200$ & 6 & 5 \\
\hline$>30,0$ & 20 & 3 & $>30,0$ & 8 & 3 & $>200$ & 8 & 5 \\
\hline
\end{tabular}

Źródło: opracowanie własne. 
krajobrazu do powierzchni gminy oraz szlaki turystyczne w $\mathrm{km}$ na $100 \mathrm{~km}^{2}$. Natomiast walory kulturowe są charakteryzowane przez liczbę najważniejszych zabytków, muzeów, targów, wystaw i imprez odbywających się $\mathrm{w}$ gminie oraz ich natężenie w ciągu roku (GOŁEMBSKI 2006).

Skala bonitacyjna to związek między cechą a zmienną przyrodniczą lub pozaprzyrodniczą oraz nadanymi jej punktami. Każdemu z poddawanych badaniu elementów środowiska przypisano odpowiednią wartość. Do analizy bonitacyjnej wykorzystane zostały trzy walory przyrodnicze: lesistość terenu, powierzchnie prawnie chronione oraz liczba pomników przyrody (tab. 1). Nie brano pod uwagę klimatu, opadów i deniwelacji, ze względu na ich małe zróżnicowanie w poszczególnych powiatach województwa łódzkiego.

Lesistość większości powiatów w centrum województwa łódzkiego mieści się w przedziale od 20,1\% do $30 \%$ (rys. 1), co jest liczbą oscylującą w okolicach średniej przypadającej na całe województwo łódzkie $(21,4 \%)$. Powiaty te tworzą tym samym najliczniejszą grupę. Przyznany im został trzeci próg punktowy z czterech możliwych, tj. 15 punktów. Trzy powiaty (tomaszowski, opoczyński oraz radomszczański) uzyskały maksymalną liczbę punktów, tj. 20, jako że lasy zajmują w nich więcej niż 30\% powierzchni. Najmniejszą lesistość, poniżej 10\%, mają dwa powiaty (kutnowski i łęczycki) oraz dwa miasta na prawach powiatu (Łódź i Skierniewice).

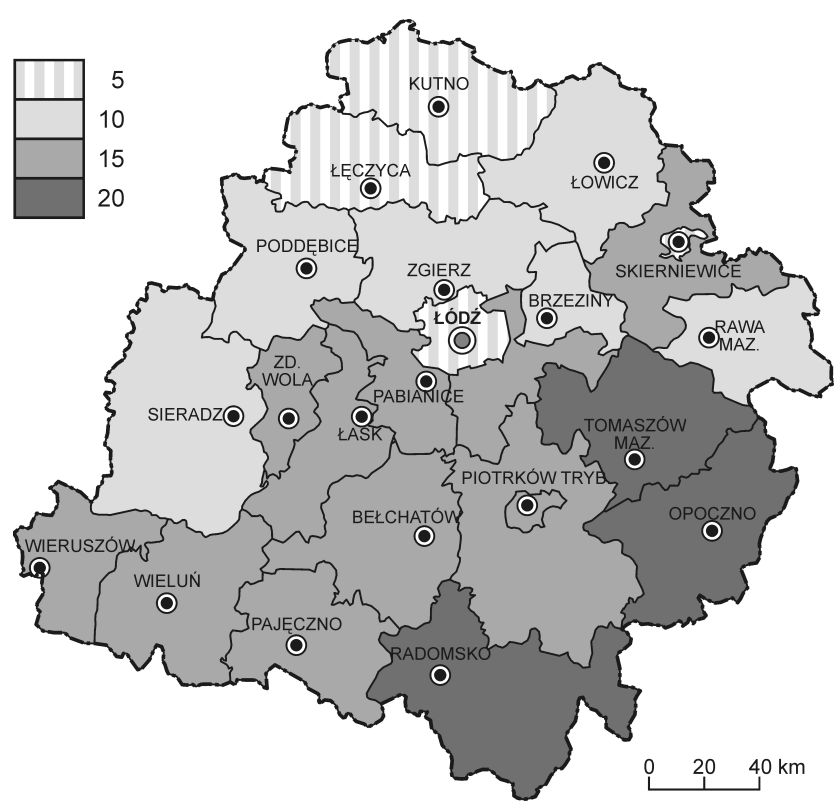

Rys. 1. Liczba punktów bonitacyjnych dla lesistości w poszczególnych powiatach woj. łódzkiego Źródło rys. 1-7: opracowanie własne

$\mathrm{W}$ ustalonej dla powierzchni prawnie chronionych czterostopniowej skali bonitacyjnej powiaty rozkładaja się dość równomiernie. $\mathrm{W}$ dziewięciu powiatach ob- szary chronione zajmują od 10 do $20 \%$, co pozwoliło na uzyskanie sześciu z ośmiu możliwych do zdobycia punktów. W siedmiu powiatach tereny te zajmują od 20,1 do $30 \%$ powierzchni. W powiatach brzezińskim, laskim i wieruszowskim odnotowano najwyższy udział (przekraczający 30\%) powierzchni prawnie chronionych. Najmniejszą wartość analizowanej zmiennej odnotowano w powiatach kutnowskim, pajęczański oraz zduńskowolskim, a także w miastach powiatowych - Skierniewicach oraz Łodzi.

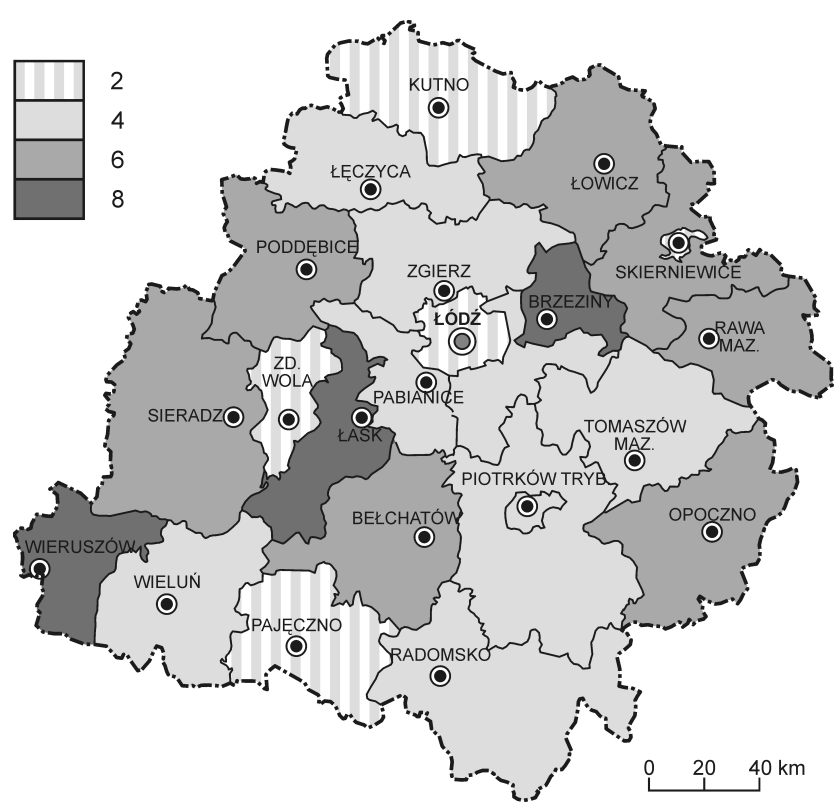

Rys. 2. Liczba punktów bonitacyjnych dla powierzchni prawnie chronionych w poszczególnych powiatach woj. łódzkiego

Z przeprowadzonej analizy wynika, że powiaty województwa łódzkiego nie są zasobne $w$ tereny prawnie chronione (rys. 2). Pomimo że, jak już zostało wspomniane, w Skierniewicach nie ma wielu tego typu terenów, to $\mathrm{w}$ powiecie otaczającym miasto jest ich już sporo, uzyskał on bowiem sześć z ośmiu możliwych do zdobycia punktów w ustalonej skali bonitacyjnej. Nierównomiernie usytuowane są w województwie łódzkim również pomniki przyrody (rys. 3). Najliczniejszą grupę stanowi dziewięć powiatów, w których obrębie zlokalizowanych jest od 51 do 100 takich pomników. Po pięć powiatów znalazło się w trzech pozostałych grupach (do 50 pomników, 101-200 i powyżej 200). Warto zaznaczyć, że na terenie powiatu tomaszowskiego znajduje się aż 566 pomników przyrody, co wyraźnie wyróżnia go na tle pozostałych, w których ich liczba nie przekracza 300. Średnia dla całego województwa wynosi około 135 pomników na powiat. Daje to regionowi łódzkiemu trzecie miejsce w kraju. Lepiej wypadają tylko województwa zachodniopomorskie (średnio 140 pomników) i pomorskie (średnio 141 pomników). W województwie łódzkim znajduje się 3249 pomników przyrody. 


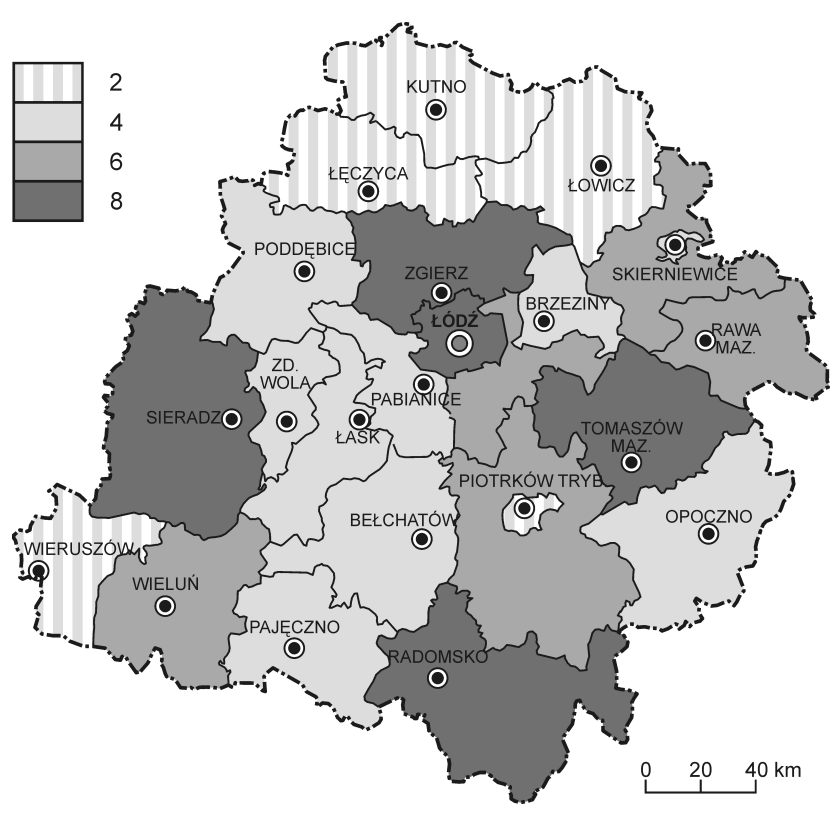

Rys. 3. Liczba punktów bonitacyjnych dla liczby pomników przyrody w poszczególnych powiatach woj. łódzkiego

W analizie bonitacji punktowej walorów przyrodniczych najkorzystniej wypadły powiaty tomaszowski oraz radomszczański (uzyskały one po 32 na 36 możliwych do zdobycia punktów). Drugie miejsce zają powiat opoczyński, który otrzymał 30 punktów. Najgorzej wypadły powiaty kutnowski (9 pkt), łęczycki oraz miasto Skierniewice (po 11 pkt). Średnia liczba punktów uzyskanych przez wszystkie powiaty wynosi 22 punkty.

W celu dokonania analizy walorów pozaprzyrodniczych wykorzystano trzy zmienne. Jedną z nich jest liczba wydarzeń kulturalnych, odbywających się w poszczególnych powiatach województwa łódzkiego. Została ona wykorzystana do analizy ze względu na rosnaccą popularność wielu eventów nie tylko wśród mieszkańców miejscowości, w których się one odbywają, ale również turystów, chętnie się tam zatrzymujących, by obejrzeć coś charakterystycznego dla danego kraju lub regionu. Druga zmienna określa liczbę zabytków zlokalizowanych na terenie powiatów województwa łódzkiego. Do tych zabytków zalicza się: parki, dwory, cmentarze, kaplice, kościoły, ratusze, dzwonnice, aleje oraz wiele budynków o różnym przeznaczeniu. Ten rodzaj waloru kulturowego występuje najliczniej ze wszystkich dostępnych walorów turystycznych. Trzecia zmienna dotyczy zabytkowych obiektów sakralnych, które wprawdzie zostały już uwzględnione w ogólnej liczbie zabytków, jednak w tym przypadku chodzi o obiekty sakralne, podkreślające różnorodność religijną regionu, takie jak: kościoły rzymskokatolickie, ewangelicko-augsburskie, cerkwie oraz synagogi. Ponadto ich część stanowią zabytkowe kaplice i dzwonnica. Informacje na temat liczby wydarzeń kulturalnych oraz liczby zabytków zostały pozyskane z bazy danych GUS i pochodzą z 2016 i 2017 r. Dane dotyczące liczby zabytkowych obiektów sakralnych pozyskano ze strony internetowej poświęconej podróżom i turystyce w województwie łódzkim (www.lodzkie.travel.pl).

Według danych zawartych w tab. 2 województwo łódzkie jest regionem, w którym odbywa się stosunkowo dużo wydarzeń kulturalnych. W tę zmienną wliczone zostały seanse filmowe, wystawy, prelekcje, spotkania i pokazy teatralne, konferencje, konkursy, warsztaty, festiwale, występy zespołów, wydarzenia sportowe, rekreacyjne i plenerowe, lekcje muzealne czy szeroko komentowane imprezy masowe. Łączna liczba wydarzeń kulturalnych, które miały miejsce w województwie łódzkim, wynosi blisko 24 tys. Jest to wartość przewyższająca o około 10 tys. średnią liczbę wydarzeń dla całej Polski. Dla porównania w województwie małopolskim w 2016 r. odbyło się niewiele ponad 30 tys. wydarzeń, na drugim miejscu znalazło się województwo mazowieckie $\mathrm{z}$ wynikiem nieprzekraczającym 30 tys., w pozostałych województwach liczba wydarzeń kulturalnych w roku oscyluje wokół 20 tys.

Najwięcej wydarzeń kulturalnych odbywa się w Łodzi oraz w otaczających ją powiatach, zwłaszcza od strony południowej (rys. 4). Najwyższą liczbę punktów (20) uzyskał również powiat bełchatowski, który jest regionem posiadającym duże zaplecze finansowe, co pozwala lokalnym władzom na zapewnianie rozrywek nie tylko dla mieszkańców, ale również dla turystów. Drugą grupę tworzą powiaty: łowicki, rawski oraz radomszczański, w których odbywa się 801-1200 wydarzeń rocznie, a najmniej organizuje się w: sieradzkim, poddębickim, łęczyckim czy zdunskowolskim.

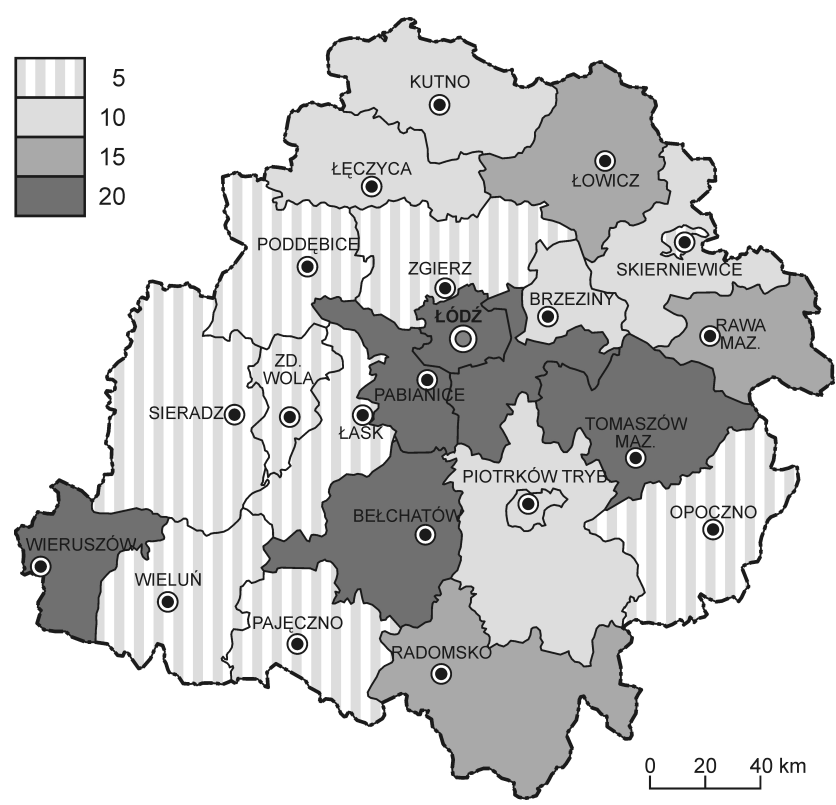

Rys. 4. Liczba punktów bonitacyjnych dla liczby wydarzeń kulturalnych w poszczególnych powiatach woj. łódzkiego 
Tab. 2. Bonitacja punktowa dla liczby wydarzeń kulturalnych, liczby zabytków oraz liczby zabytkowych obiektów sakralnych 5

\begin{tabular}{|l|c|c|c|c|c|c|c|c|}
\hline \multicolumn{7}{|c|}{ Bonitacja punktowa dla liczby } \\
\hline $\begin{array}{c}\text { wrzedziały } \\
\text { liczbowe }\end{array}$ & $\begin{array}{c}\text { przyznane } \\
\text { punkty }\end{array}$ & $\begin{array}{c}\text { liczba } \\
\text { powiatów }\end{array}$ & $\begin{array}{c}\text { przedziały } \\
\text { liczbowe }\end{array}$ & $\begin{array}{c}\text { przyznane } \\
\text { punkty }\end{array}$ & $\begin{array}{c}\text { liczba } \\
\text { powiatów }\end{array}$ & $\begin{array}{c}\text { pabytkowych obiektów sakralnych } \\
\text { liczbowe }\end{array}$ & $\begin{array}{c}\text { przyznane } \\
\text { punkty }\end{array}$ & $\begin{array}{c}\text { liczba } \\
\text { powiatów }\end{array}$ \\
\hline $0-400$ & 5 & 9 & $0-50$ & 5 & 6 & $0-5$ & 5 & 4 \\
\hline $401-800$ & 10 & 6 & $51-100$ & 10 & 5 & $6-10$ & 10 & 6 \\
\hline $801-1200$ & 15 & 3 & $101-150$ & 15 & 9 & $11-15$ & 15 & 9 \\
\hline Powyżej 1200 & 20 & 6 & powyżej 150 & 20 & 4 & powyżej 15 & 20 & 5 \\
\hline
\end{tabular}

Źródło: opracowanie własne.

Rozmieszczenie zabytków wygląda następująco: w dziewięciu z 24 powiatów znajduje się od 101 do 150 zabytków. Kolejne cztery powiaty posiadają więcej niż 150 zabytków. W powiecie sieradzkim znajduje się ich 174, w kutnowskim - 213, w lowickim - 218, natomiast $w$ mieście Łodzi jest ich 599. Najmniej zabytków jest zlokalizowanych w powiatach: łaskim, lódzkim wschodnim, pabianickim, pajęczańskim, wieruszowskim oraz zduńskowolskim (rys. 5). Najbogatsze $\mathrm{w}$ zabytki są powiaty $\mathrm{w}$ północnej oraz wschodniej i południowo-wschodniej części województwa łódzkiego (rys. 5). W części zachodniej wyróżnia się natomiast powiat sieradzki. Powiaty te uzyskały $15 \mathrm{lub}$ 20 punktów w czterostopniowej skali bonitacyjnej. $\mathrm{W}$ powiatach otaczających stolicę województwa od strony południowej nie ma zbyt wielu obiektów zabytkowych, co skutkuje przyznaniem najniższej noty, tj. 5 punktów.

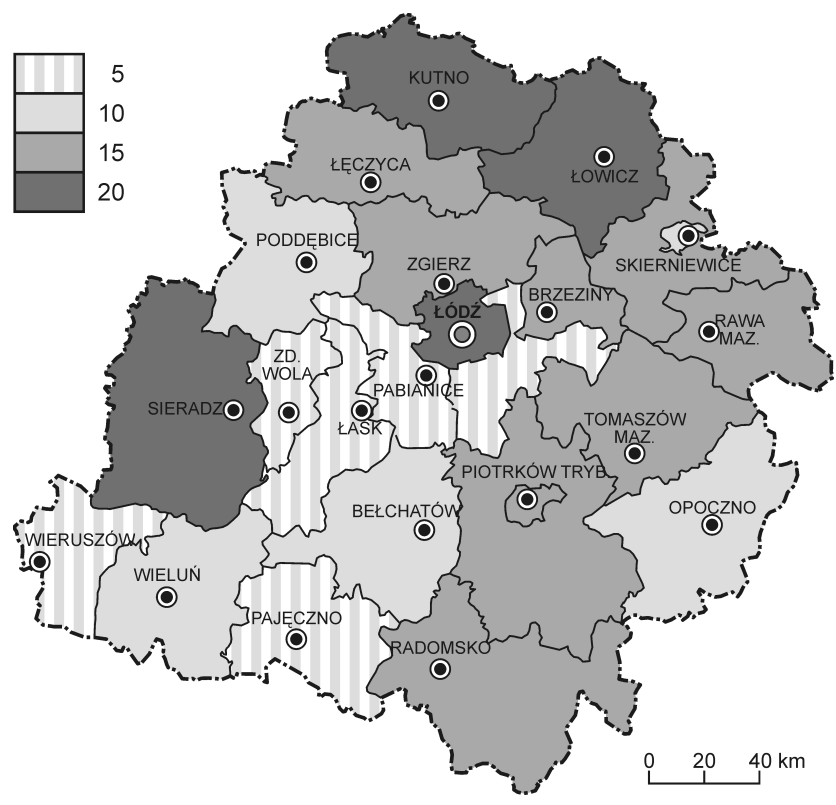

Rys. 5. Liczba punktów bonitacyjnych dla liczby zabytków w poszczególnych powiatach woj. łódzkiego
Rozkład ogólnej liczby powiatów na poszczególne przedziały bonitacyjne jest dość równomierny. Na tle 24 powiatów województwa łódzkiego wyróżnia się dziewięć, w których znajduje się od 11 do 15 zabytkowych obiektów sakralnych. Powiaty te uzyskały 15 z 20 możliwych do zdobycia punktów w ustalonej czterostopniowej skali. Najmniej liczna jest grupa powiatów, w których znajduje się do pięciu obiektów antropogenicznych. Zaledwie w pięciu powiatach zlokalizowanych jest ponad 15 zabytkowych obiektów.

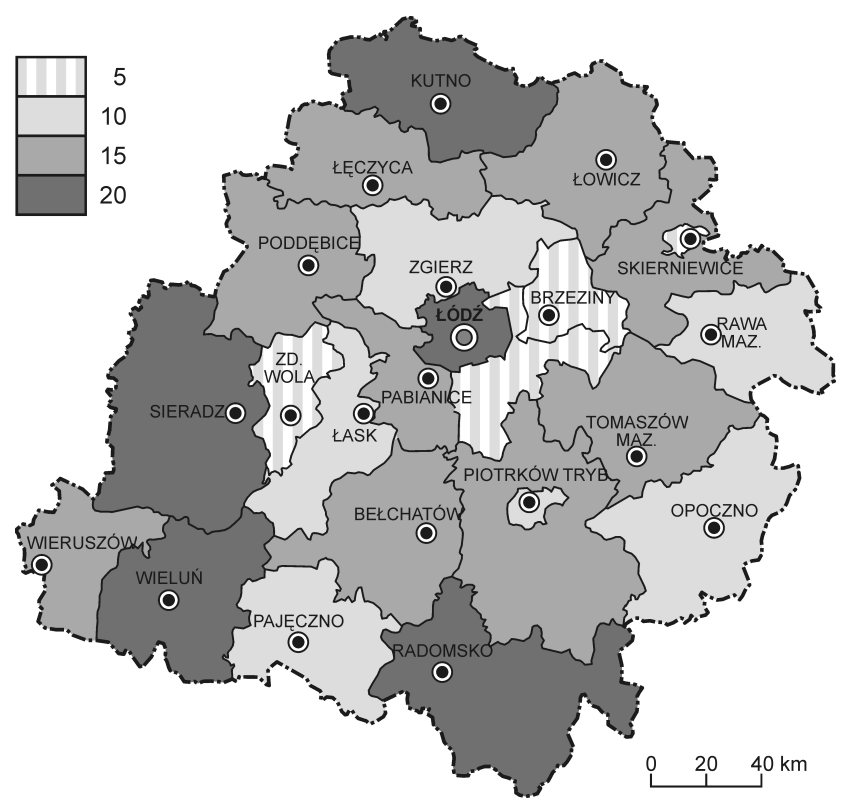

Rys. 6. Liczba punktów bonitacyjnych dla liczby zabytkowych obiektów sakralnych w poszczególnych powiatach woj. łódzkiego

W przypadku obiektów sakralnych nie zarysowuje się wyraźna tendencja do koncentracji ich w centralnej części województwa, tj. w Łodzi. Największą liczbę punktów w odniesieniu do tej zmiennej uzyskały powiaty: sieradzki, wieluński, radomszczański, kutnowski oraz Łódź (rys. 6). Zlokalizowanych jest w nich 
odpowiednio: 20, 19, 18, 17 oraz 16 zabytków sakralnych. Najmniej tego typu obiektów znajduje się w Skierniewicach oraz w powiecie łódzkim wschodnim, brzezińskim i zduńskowolskim.

Miasto Łódź uzyskało łącznie 60 punktów. Na drugim miejscu znalazły się cztery powiaty (tomaszowski, radomszczański, łowicki oraz kutnowski), które otrzymały 50 punktów bonitacyjnych. Skierniewice, powiat łaski oraz pajęczański dostały po 20 punktów. Pozostałe powiaty uzyskały od 25 do 45 punktów. Najniżej w rankingu znalazł się powiat zduńskowolski z 15 punktami. Średnia dla wszystkich 24 powiatów wynosi 37 punktów.

Najwięcej powiatów (7) mieści się w przedziale od 37 do 47 uzyskanych punktów. W pozostałych przedziałach punktowych było mniej powiatów (szczególnie $w$ przedziale od 15 do 25 punktów). Miasto Łódź uzyskało maksymalną liczbę punktów bonitacyjnych (20) w każdej zmiennej, natomiast najgorzej wypadł powiat zduńskowolski, który trzykrotnie otrzymał najniższą notę, tj. 5 punktów.

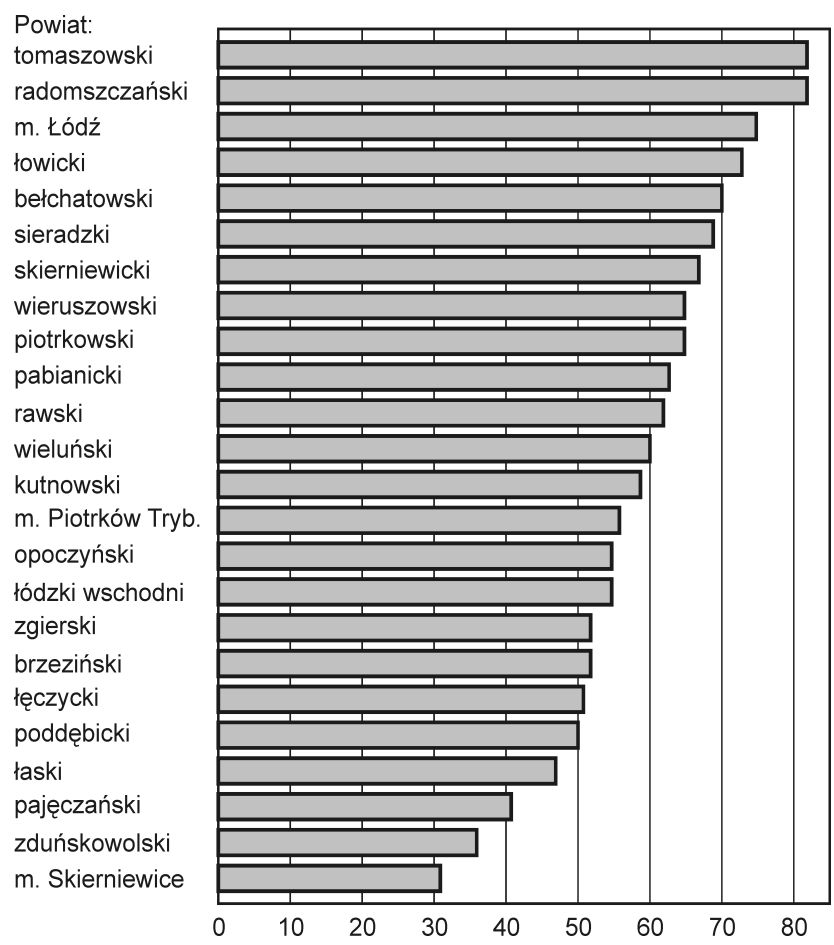

Rys. 7. Ranking według sumy punktów dla walorów przyrodniczych i kulturowych w poszczególnych powiatach woj. łódzkiego

Na rys. 7 przedstawiono ranking powiatów województwa łódzkiego, stworzony na podstawie sumy punktów bonitacyjnych dla walorów przyrodniczych i kulturowych. W tym przypadku najkorzystniej wypadały powiaty tomaszowski oraz radomszczański, mające po 82 punkty, co stanowi $85 \%$ możliwych do uzyskania punktów (96).
Najliczniejszą grupę stanowią powiaty, które otrzymały od 53 do 63 punktów bonitacyjnych, czyli: łódzki wschodni, opoczyński, kutnowski, wieluński, rawski, pabianicki oraz miasto Piotrków Trybunalski. Najmniej punktów, tj. od 31 do 41, uzyskały tylko nieliczne powiaty - miasto Skierniewice, powiat zduńskowolski oraz pajęczański.

\section{WALORY TURYSTYCZNE A ROZMIESZCZENIE BAZY NOCLEGOWEJ W WOJEWÓDZTWIE ŁÓDZKIM}

W niniejszym artykule zaprezentowano analizy wartości korelacyjnych pomiędzy poszczególnymi walorami przyrodniczymi i pozaprzyrodniczymi a liczbą miejsc noclegowych dla powiatów województwa łódzkiego 6 .

Tab. 3. Analiza korelacji wybranych walorów turystycznych określonych metodą bonitacji punktowej i rozmieszczenia turystycznej bazy noclegowej

\begin{tabular}{|c|l|c|}
\hline Lp. & Wybrane walory turystyczne & $\begin{array}{c}\text { Współczynnik ko- } \\
\text { relacji rang Spear- } \\
\text { mana pomiędzy } \\
\text { wybranymi walora- } \\
\text { mi turystycznymi } \\
\text { a rozmieszczeniem } \\
\text { bazy noclegowej }\end{array}$ \\
\hline 1 & Lesistość & 0,039 \\
\hline 2 & $\begin{array}{l}\text { Udział powierzchni prawnie } \\
\text { chronionych }\end{array}$ & $-0,138$ \\
\hline 3 & $\begin{array}{l}\text { Występowanie pomników przy- } \\
\text { rody }\end{array}$ & 0,457 \\
\hline 4 & $\begin{array}{l}\text { Suma wybranych walorów } \\
\text { przyrodniczych }\end{array}$ & 0,125 \\
\hline 5 & Liczba wydarzeń kulturalnych & 0,277 \\
\hline 6 & Liczba zabytków & 0,228 \\
\hline 7 & $\begin{array}{l}\text { Liczba zabytkowych obiektów } \\
\text { sakralnych }\end{array}$ & 0,298 \\
\hline 8 & $\begin{array}{l}\text { Suma wybranych walorów } \\
\text { kulturowych }\end{array}$ & 0,381 \\
\hline
\end{tabular}

Źródło: opracowanie własne.

Analizując tab. 3 można zauważyć, iż rozmieszczenie bazy noclegowej pozostaje w silniejszym związku z uwzględnionymi w badaniu walorami kulturowymi $(0,381)$ niż z walorami przyrodniczymi $(0,125)$. Nie stwierdzono korelacji pomiędzy lesistością a liczbą miejsc noclegowych ani między udziałem powierzchni prawnie chronionych a rozmieszczeniem turystycznej bazy noclegowej. Najwyraźniej widać zależność między występowaniem pomników przyrody a rozmieszczeniem turystycznej bazy noclegowej $(0,457)$ - jest to korelacja dodatnia umiarkowana. Spo- 
śród walorów antropogenicznych najwyższą wartością korelacji charakteryzuje się liczba obiektów sakralnych $(0,298)$. Na drugim miejscu - liczba wydarzeń kulturalnych $(0,277)$, a na trzecim - liczba zabytków $(0,228)$. Na podstawie tych wyników można stwierdzić, że występuje tu zależność zauważalna, ale niska.

\section{PODSUMOWANIE I WNIOSKI}

Podsumowując opracowaną analizę należy zwrócić uwagę na fakt, że nie wykazano zależności pomiędzy stopniem lesistości powiatów a liczbą miejsc noclegowych. Najlepszym tego przykładem jest Łódź, która przy lesistości na poziomie 9,3\% ma najwięcej miejsc noclegowych w całym województwie. Inną egzemplifikację stanowi powiat opoczyński, w którym pomimo najwyższego poziomu lesistości ze wszystkich 24 powiatów województwa łódzkiego, znajdują się jedynie 174 miejsca noclegowe. Dobrym przykładem występowania opisanej tu korelacji jest powiat tomaszowski, w którego przypadku udział gruntów leśnych w powierzchni powiatu jest najwyższy i przekłada się to na liczbę miejsc noclegowych.

Nie odnotowano silnego związku między powierzchniami chronionymi a rozmieszczeniem miejsc noclegowych. Najlepiej wypadają tu powiaty rawski i bełchatowski, w których można zaobserwować zależność między tymi cechami. Najgorzej natomiast prezentuje się miasto Łódź, które posiadając największą liczbę miejsc noclegowych, charakteryzuje się niskim udziałem powierzchni prawnie chronionych (mniej niż $10 \%$ ). W przypadku powiatu tomaszowskiego, piotrkowskiego, zgierskiego oraz Łodzi widać wyraźną zależność między liczbą pomników przyrody a liczbą miejsc noclegowych. Zauważalna jest także tendencja wskazująca, że wraz ze wzrostem liczby wydarzeń kulturalnych zwiększa się liczba miejsc noclegowych. Tak przedstawia się sytuacja w Łodzi oraz w powiecie bełchatowskim i tomaszowskim.

Kolejnym walorem jest liczba zabytków w poszczególnych powiatach województwa. Można wskazać powiaty, gdzie duża liczba miejsc noclegowych występuje w pobliżu zabytków, jak np. w Łodzi oraz w powiecie rawskim, bełchatowskim i wielunskim. Natomiast są też powiaty (łowicki i kutnowski), w których mimo dużej liczby zabytków zarejestrowano niewiele miejsc noclegowych.

Nie dostrzeżono ścisłej zależności między ostatnim z walorów kulturowych w powiecie łódzkim - liczbą zabytkowych obiektów sakralnych - a rozmieszczeniem liczby miejsc noclegowych. Tylko w kilku powiatach można zauważyć związek pomiędzy dużą liczbą zabytkowych obiektów sakralnych a liczbac miejsc noclegowych. Przykładem jest tutaj powiat wie- luński, w którym zlokalizowane są 22 obiekty sakralne oraz 1154 miejsca noclegowe. Podobnie wygląda sytuacja w przypadku miasta Skierniewice, w którym znajdują się trzy zabytkowe obiekty sakralne, a liczba miejsc noclegowych jest jedną z najniższych i wynosi jedynie 48 .

Wyniki przeprowadzonych badań umożliwiają udzielenie odpowiedzi na postawione na początku niniejszego opracowania pytania badawcze. Na podstawie dokonanych analiz można stwierdzić, że wynik korelacji rang Spearmana dla danych dotyczących walorów przyrodniczych nie potwierdza postawionej hipotezy, że walory przyrodnicze mają największy wpływ na rozmieszczenie turystycznej bazy noclegowej w województwie łódzkim. Dla wybranych walorów przyrodniczych był to wynik równy 0,125, natomiast dla walorów kulturowych - 0,381, co wskazuje, iż te drugie silniej oddziałują na rozmieszczenie turystycznej bazy noclegowej. Analizując poszczególne walory przyrodnicze, można dojść do wniosku, że największy wpływ na lokalizację turystycznej bazy noclegowej ma liczba pomników przyrody, a więc nie potwierdziła się hipoteza druga, o najsilniejszym oddziaływaniu obszarów prawnie chronionych. Pozwala to stwierdzić, że występowaniu wielu walorów turystycznych nie zawsze towarzyszy turystyczna baza noclegowa, jednak w niewielkim stopniu są one ze sobą powiązane. Natomiast w województwie łódzkim na rozmieszczenie bazy noclegowej silniej wpływają walory kulturowe niż walory przyrodnicze.

\section{PRZYPISY}

${ }^{1}$ Artykuł powstał na podstawie pracy magisterskiej S. ŻAKOWSKA (2018).

2 Walory antropogeniczne uzupełniono wykazem obiektów wpisanych do rejestru zabytków województwa łódzkiego.

${ }^{3}$ Stan $\mathrm{z}$ dnia 30.06.2017 r.

4 Stan z dnia 15.02.2018 r.

5 Skala punktów bonitacyjnych została ustalona od 5 do 20 dla lepszej czytelności wskaźnika.

${ }^{6}$ Do interpretacji wyników przyjęto metodę przedstawioną w publikacji Statystyka: elementy teorii $i$ zadania (OSTASIEWICZ, RUSNAK, SIEDLECKA 1999).

\section{BIBLIOGRAFIA}

BALIŃSKA A., SIECZKO A., ZAWADKA J., 2014, Turystyka: wybrane zagadnienia, Difin, Warszawa.

BANASZCZYK P., TUMIŁOWICZ J., 2000, Arboretum w Rogowie, Multico Oficyna Wydawnicza, Warszawa.

BAR R., DOLIŃSKI A., 1978, Turystyka, Wydawnictwo Szkolne i Pedagogiczne, Warszawa.

BEETON S., 2005, Film-induced tourism, Channel View Publications, Bristol.

BORZYSZKOWSKI J., 2011, Organizacja i zarządzanie turystyką w Polsce, CeDeWu, Warszawa. 
BUCZKOWSKA K., 2008, Turystyka kulturowa. Przewodnik metodyczny, Akademia Wychowania Fizycznego, Poznań.

DEREK M., 2010, Turystyka przemystowa jako forma turystyki zrównoważonej, [w:] Z. Młynarczyk, I. Potocka, A. Zajadacz (red.), Uwarunkowania i plany rozwoju turystyki, t. 6: Turystyka zrównoważona, Bogucki Wydawnictwo Naukowe, Poznań, s. 31-41.

DEREK M., KOWALCZYK A., 2010, Zagospodarowanie turystyczne, Wydawnictwo Naukowe PWN, Warszawa.

DRABAREK A., 2011, Atrakcyjność turystyczna a rozmieszczenie bazy noclegowej w Indonezji w poczatkach XXI wieku, praca magisterska, Uniwersytet Warszawski, Warszawa.

DurYdiWKA M., DUDA-GROMADA K. (red.), 2011, Przestrzeń turystyczna. Czynniki, różnorodność, zmiany, Uniwersytet Warszawski, Warszawa.

DYLIK J., DYLIK Z., KACZMAREK R., 1954, Województwo tódzkie: przewodnik turystyczny, Wydawnictwo "Sport i Turystyka", Warszawa.

GAWORECKI W., 2007, Turystyka, Polskie Wydawnictwo Ekonomiczne, Warszawa.

GOŁEMBSKI G. (red.), 1999, Regionalne aspekty rozwoju turystyki, Wydawnictwo Naukowe PWN, Warszawa-Poznań.

GOŁEMBSKI G. (red.), 2006, Kompendium wiedzy o turystyce, Wydawnictwo Naukowe PWN, Warszawa.

JĘDRYSIAK T., 2008, Turystyka kulturowa, Polskie Wydawnictwo Ekonomiczne, Warszawa.

KACZMAREK S., 2001, Rewitalizacja terenów poprzemystowych. Nowy wymiar w rozwoju miast, Wydawnictwo Uniwersytetu Łódzkiego, Łódź.

KOTER M., LISZEWSKI S., SULIBORSKI A., 1999, Łódź i region Polski środkowej: podręcznik wiedzy o regionie dla liceów, Łódzkie Towarzystwo Naukowe, Łódź.

KOWALCZYK A. (red.), 2010, Turystyka zrównoważona, Wydawnictwo Naukowe PWN, Warszawa.

KOWALCZYK A., 2001, Geografia turyzmu, Wydawnictwo Naukowe PWN, Warszawa.

KOŻUCHOWSKI K., 2005, Walory przyrodnicze w turystyce i rekreacji (Podręcznik akademicki), Wydawnictwo Kurpisz S.A., Poznań.

KRONENBERG M., 2012, Wptyw zasobów dziedzictwa przemystowego na atrakcyjność turystycznq miasta: przykład Łodzi, Wydawnictwo Uniwersytetu Łódzkiego, Łódź.

KRONENBERG M., 2016, Potencjat turystyczny dziedzictwa filmowego w województwie tódzkim, Centrum Inicjatyw na rzecz Rozwoju REGIO, Łódź.

KRUCZEK Z., 2005, Polska. Geografia atrakcji turystycznych, Wydawnictwo Proksenia, Kraków.

KRZYMOWSKA-KOSTROWICKA A., 1999, Geoekologia turystyki i wypoczynku, Wydawnictwo Naukowe PWN, Warszawa.

KUREK W. (red.), 2007, Turystyka, Wydawnictwo Naukowe PWN, Warszawa.

KUROWSKI J.K., 2013, Obszary NATURA 2000 w województwie tódzkim, Regionalna Dyrekcja Ochrony Środowiska, Łódź.

LIJEWSKI T., MIKUŁOWSKI B., WYRZYKOWSKI J., 2002, Geografia turystyki Polski, PWE, Warszawa.

LISZEWSKI S., 2008, Miasto jako przedmiot badań geografii turyzmu w Polsce, ,Turyzm”, 18, 1, s. 27-38.

ŁUKASZEWICZ A., 1987, Ogrody botaniczne $i$ arboreta w Polsce, Państwowe Wydawnictwo Rolnicze i Leśne, Warszawa.

MEDLIK S., 1995, Leksykon podróży, turystyki, hotelarstwa, PWN, Warszawa.

MOKRAS-GRABOWSKA J., 2014, Przestrzeń turystyczno-artystyczna Łodzi na przykładzie Galerii Urban Forms, „Turyzm/Tourism”, 24,2 , s. 25-33.

Największe atrakcje turystyczne Łodzi i regionu tódzkiego, Regionalna Organizacja Turystyczna Województwa Łódzkiego, Oficyna Wydawniczo-Reklamowa SAGALARA, Łódź.
OLACZEK R., 2013, Ochrona przyrody w lasach Regionalnej Dyrekcji Lasów Państwowych w Łodzi i województwa tódzkiego, Oficyna Wydawnicza FOREST, Józefów.

OSTASIEWICZ S., RUSNAK Z., SIEDLECKA U., 1999, Statystyka: elementy teorii i zadania, Wydawnictwo Akademii Ekonomicznej im. Oskara Langego, Wrocław.

PANASIUK A., SZOSTAK D., 2009, Hotelarstwo. Ustugi - eksploatacja - zarzadzanie, Wydawnictwo Naukowe PWN, Warszawa.

PAWLIKOWSKA-PIECHOTKA A., 2009, Zagospodarowanie turystyczne i rekreacyjne, Wydawnictwo Novae Res, Gdynia.

PIRASZEWSKA K., 2004, Przyrodnicze uwarunkowania rozmieszczenia turystycznej bazy noclegowej w Tajlandii, praca magisterska, Uniwersytet Warszawski, Warszawa.

Program rozwoju turystyki w województwie tódzkim na lata 20072020, 2007, Warszawa-Łódź.

PRZECŁAWSKI K., 1997, Człowiek a turystyka. Zarys socjologii turystyki, Wydawnictwo Albis, Kraków.

Państwowe Gospodarstwo Leśne Lasy Państwowe, 2017, Raport o stanie lasów w Polsce 2016, Centrum Informacyjne Lasów Państwowych, Warszawa.

ROGALEWSKI O., 1972, Podstawy gospodarki przestrzennej w turystyce, ser. "Ruch Turystyczny - Monografie”, 13, Szkoła Główna Planowania i Statystyki, Warszawa.

SOŁOWIEJ D., 1992, Podstawy metodyki oceny środowiska przyrodniczego człowieka, Wydawnictwo Naukowe Uniwersytetu im. Adama Mickiewicza, Poznań.

Strategia Rozwoju Województwa Łódzkiego 2020, 2006, Zarząd Województwa Łódzkiego, Łódź.

Strategia Rozwoju Województwa Łódzkiego na lata 2007-2020, 2006, Zarząd Województwa Łódzkiego, Łódź.

SZWICHTENBERG A. (red.), 2000, Podstawy turystyki, Politechnika Koszalińska, Koszalin.

TERTELIS P., 2012, Walory turystyczne a rozmieszczenie bazy noclegowej w Nepalu na początku XXI wieku, praca magisterska, Uniwersytet Warszawski, Warszawa.

Ustawa z dnia 29 sierpnia 1997 r. o ustugach turystycznych, DzU, nr 133, poz. 884 ze zmianami.

WARSZYŃSKA J., JACKOWSKI A., 1978, Podstawy geografii turyzmu, PWN, Warszawa.

WIĘCKOWSKI M., 2014, Przestrzeń turystyczna - próba nowego spojrzenia, „Turyzm/Tourism”, 24, 1, s. 17-24.

WŁODARCZYK B., 2009, Przestrzeń turystyczna. Istota, koncepcje, determinanty rozwoju, Wydawnictwo Uniwersytetu Łódzkiego, Łódź.

WŁODARCZYK B., 2014, Przestrzen w turystyce, turystyka w przestrzeni - o potrzebie definicji, delimitacji $i$ klasyfikacji, „Turyzm/Tourism", 24, 1, s. 25-35.

WODEJKO S., 1997, Ekonomiczne zagadnienia turystyki, Wyższa Szkoła Handlu i Prawa, Warszawa.

ŻAKOWSKA S., 2018, Walory turystyczne a rozmieszczenie turystycznej bazy noclegowej w województwie w łódzkim, praca magisterska, Wydział Geografii i Studiów Regionalnych, Uniwersytet Warszawski, Warszawa.

www.arboretum.sggw.pl/historia.html; 15.05 .2018 r.

www.arboretum.sggw.pl/polozenie.html; 15.05.2018 r.

www.bdl.stat.gov.pl; $22.05 .2018 \mathrm{r}$.

www.czasnarower.pl; $22.05 .2018 \mathrm{r}$.

www.erih.net; 02.12.2017 r.

www.ec.europa.eu/culture/european-year-cultural-heritage2018 en; 10.12.2017 r.

www.historycznie.uni.lodz.pl/poczatek.htm; $18.04 .2018 \mathrm{r}$. www.hotelarze.pl/hot/bl-hotelarstwo-18w.php; 19.04.2018 r. www.kajaki.pttk.pl/index.php?id=turystyka-kwalifikowana; 20.04.2018 r

www.kampinoski-pn.gov.pl/edukacja/ohz-w-smardzewicach; 24.05.2018 r 
www.klubgaja.pl; 04.04.2018 r

www.kreatywna-europa.eu/europejski-rok-dziedzictwa-kultu rowego-2018/; 02.12.2017 r.

www.ktpzg.pttk.pl/szlaki/szlaki.php; 15.11.2017 r.

www.kultura.lodz.pl; 18.04.2018 r

www.lodz.pttk.pl; 15.11.2017 r.

www.lodzkie.travel/?kat=ochrona_przyrody\&sub=7\&sort=n; 10.12.2017 r

www.lodzkie.travel/?kat=swiatynie; 13.04.2018 r.

www.mapa.lodz.pl/portal/apps/webappviewer/index.html?id

$=7489987 \mathrm{eb60a} 4369814 \mathrm{e} 53 \mathrm{~d} 49 \mathrm{cc} 58 \mathrm{ff}$ \& extent $=19.317,51.7126$,

19.6459,51.8507; $18.04 .2018 \mathrm{r}$.

www.nieborow.art.pl/ogrody/; 28.03.2018 r.

www.nieborow.art.pl/o-muzeum/historia-palacu/; 28.03.2018 r. www.nieborow.art.pl/o-muzeum/www.wuoz-lodz.pl; 28.03 $2018 \mathrm{r}$.

www.parkilodzkie.pl/npk/edukacja/spalski-park-krajobrazo wy; $22.05 .2018 \mathrm{r}$.

www.parkilodzkie.pl/npk/przedborski-pk; $22.05 .2018 \mathrm{r}$.

www.parkilodzkie.pl/npk; 22.05.2018 r.

www.parkilodzkie.pl/pkwl/o-parku/kultura; 22.05.2018 r

www.parkilodzkie.pl/pkwl/turystyka/leksykon?start=10; 22. $05.2018 \mathrm{r}$.

www.parkilodzkie.pl/pkwl/turystyka/szlaki-turystyczne/278zielony-szlak-pieszy-po-parku-krajobrazowym-wzniesienlodzkich; 22.05.2018 r. www.parkilodzkie.pl/pkwl/turystyka/szlaki-turystyczne/345czarny-szlak-rowerowy-po-pkwl-opis-trasy-z-kilometrazem; 22.05.2018 r.

www.parkilodzkie.pl/pkwl/turystyka/szlaki-turystyczne; 22.05. $2018 \mathrm{r}$.

www.parkilodzkie.pl/spk/pk-miedzyrzecza-warty-i-widawki; 22.05.2018 r.

www.parkilodzkie.pl/spk/zaleczanski-pk; 22.05.2018 r.

www.pl.cit.lodz.pl/pokaz/1266,5,97,szlak-rowerowy-po-parkukrajobrazowym-wzniesien-lodzkichwww.regiocentrum.pl; 22.05.2018 r.

www.pl.cit.lodz.pl/pokaz/1266,5,97,szlak-rowerowy-po-parkukrajobrazowym-wzniesien-lodzkich; 25.05.2018 r.

www.pl.cit.lodz.pl/pokaz/1321,8,97,szlaki-rowerowe-lasu-lagie wnickiego; 25.05.2018 r.

www.pttk.pl/kznw/kanon.php; 20.05.2018 r.

www.regiocentrum.pl/pobierz/szlak-filmowy-wojewodztwalodzkiego.pdf; $28.05 .2018 \mathrm{r}$.

www.turystyka.wielun.pl; 22.05.2018 r.

www.turystyka.wielun.pl/pl/poi/3273263; 22.05.2018 r. www.turystyka.wielun.pl/pl/search?query=Przedborski+Park

+Krajobrazowy; 22.05.2018 r.

www.turyzm.pl; 20.12.2017 r.

www.uml.lodz.pl/czas-wolny/zielen-i-rekreacja/ogrod-botani czny; 15.05.2018 r.

www.wuoz.bip.lodz.pl/page/12,zabytki.html; 18.04.2018 r. 